\title{
The spectator in the interval : Corneliu Porumboiu's The second game (2014) and Marta Popivoda's Mass ornament 1 (2013)
}

\author{
Pfeifer, Patricia
}

\begin{abstract}
Based on the cutting-edge exhibit The Seductiveness of the Interval in the Romanian pavilion at the 2009 Venice Biennale, this essay proposes using the idea of the interval as an interdisciplinary concept to analyse common aesthetic traits in Corneliu Porumboiu's film Al doilea joc/The Second Game (2014) and Marta Popivoda's 3-channel installation Mass Ornament 1 (2013). The author claims that the interval has been employed in a series of recent films and art projects to address and visualise the social and political transformations in post-communist societies. Through a comparative analysis of the viewing positions and spatial constellations in Porumboiu's film and Marta Popivoda's installation, the article examines the aesthetic-epistemological function of the interval and the role of the viewer within it.
\end{abstract}

DOI: https://doi.org/10.1080/2040350X.2017.1360463

Posted at the Zurich Open Repository and Archive, University of Zurich

ZORA URL: https://doi.org/10.5167/uzh-148689

Journal Article

Published Version

Originally published at:

Pfeifer, Patricia (2017). The spectator in the interval : Corneliu Porumboiu's The second game (2014) and Marta Popivoda's Mass ornament 1 (2013). Studies in Eastern European Cinema, Vol. 8(3):232-251.

DOI: https://doi.org/10.1080/2040350X.2017.1360463 


\section{Studies in Eastern European Cinema}

\section{The spectator in the interval: Corneliu Porumboiu's The Second Game (2014) and Marta Popivoda's Mass Ornament \#1 (2013)}

\section{Patricia Pfeifer}

To cite this article: Patricia Pfeifer (2017) The spectator in the interval: Corneliu Porumboiu's The Second Game (2014) and Marta Popivoda's Mass Ornament \#1 (2013), Studies in Eastern European Cinema, 8:3, 232-251, DOI: 10.1080/2040350X.2017.1360463

To link to this article: https://doi.org/10.1080/2040350X.2017.1360463

Published online: 04 Aug 2017.

Submit your article to this journal $\sqsubset$

Џ Article views: 50

Q View related articles $\sqsubset$

View Crossmark data ¿ 


\title{
The spectator in the interval: Corneliu Porumboiu's The Second Game (2014) and Marta Popivoda's Mass Ornament \#1 (2013)
}

\author{
Patricia Pfeifer \\ Department of Film Studies, University of Zurich (UZH), Zurich, Switzerland
}

\begin{abstract}
Based on the cutting-edge exhibit The Seductiveness of the Interval in the Romanian pavilion at the 2009 Venice Biennale, this essay proposes using the idea of the interval as an interdisciplinary concept to analyse common aesthetic traits in Corneliu Porumboiu's film Al doilea joc/The Second Game (2014) and Marta Popivoda's 3-channel installation Mass Ornament \#1 (2013). The author claims that the interval has been employed in a series of recent films and art projects to address and visualise the social and political transformations in post-communist societies. Through a comparative analysis of the viewing positions and spatial constellations in Porumboiu's film and Marta Popivoda's installation, the article examines the aesthetic-epistemological function of the interval and the role of the viewer within it.
\end{abstract}

\section{KEYWORDS}

Interval; post-communism; Romanian cinema; Romanian art experimental film; installation art; Corneliu Porumboiu; Marta Popivoda

\section{Introduction}

The past is never there waiting to be discovered, to be recognized for exactly what it is. History always constitutes the relation between a present and its past. (Berger 1972,11)

The way we situate ourselves within space largely influences the way we perceive the things happening around us. Whether we stand in the middle of a room or in the left corner makes a difference. Our experience changes yet again if we position ourselves directly in a doorframe, with one room in front and another behind us. What interests me in the following is this sense of not only spatial but also temporal in-betweenness, which can best be emphasised by specific media constellations that enable fusions and simultaneously make use of different perceptual as well as technological modes. This applies, in particular, to two works I would like to discuss in more detail: Corneliu Porumboiu's 2014 film Al doilea joc/The Second Game and the video installation Mass Ornament \#1 by Marta Popivoda. Both, Porumboiu and Popivoda, deliberately create a form of inbetweenness in order to regard their subject, namely the historical past, from a new perspective. Before turning to my main objects of study, however, I would like to briefly address an art project that serves as the basis of my deliberations. 
At the 2009 Venice Biennale, which was held under the motto 'Making Worlds', the Romanian pavilion presented the site-specific installation The Seductiveness of the Interval. In cooperation with the architectural team of studioBASAR, artists Stefan Constantinescu, Andrea Faciu and Ciprian Mureşan designed a labyrinthine construction through which visitors were guided. Seen from the outside, the installation was a low, bunker-like construction, overgrown with grass, moss and plants (Figure 1). The inside was organised as a tour through several stations. Open passages painted in white alternated with five closed, dark rooms featuring video projections and installations by the three artists. At the narrative level, the exhibited works dealt with experiences of everyday violence, emigration and exile. ${ }^{1}$ In terms of its spatial arrangement, however, the installation addressed something more, namely finding oneself in a parallel or anachronistic perceptual mode, structured by small disruptions, as was indicated by the rhythmic succession of narratively filled spaces and empty passages. Situated on the boundary between the exhibition space of the pavilion and the architectural construction, the inner time of the installation represented the movement through an interstitial time and space, in other words, the movement through an interval.

As curator Alina Șerban explains:

At the heart of our fascination with strangeness, otherness, and the unfamiliar is a distinctive utopian or mystical understanding of life. The clash between nature and artifice, between appearance and reality, between hope and despair disseminates particular individual utterances that allow reality to be experienced differently, fragility to become evident and imagination to designate a space which is not bound to the laws of the quotidian. $(2010,9$, emphasis in original)

According to Șerban, the idea of the site-specific installation is, for a brief moment, to give visitors a chance to experience reality as fragmented and contradictory. The sense of in-betweenness refers not least to the transformed social and political circumstances in Romania, the state of a post-communist society confronted with a multitude of small fissures that give birth to peculiar anachronisms in everyday life. Although the installation only references Romanian history, especially the transition of 1989, indirectly, it confronts the spectator with an approach that could be described as discursive and historiographic. An inconspicuous, yet essential element in this respect is a small staircase at the end of the tour, which leads the visitors from the level of the passages to an elevated viewing platform, where they can look at the architectural design of the installation and the other visitors from above. This shift from narrative immersion during the tour (which, as the title suggests, is declared to be seductive) to a retrospective view from the outside is significant. It contains an inherently metahistorical reading, which, as Mirela Duculescu explains, establishes a 'relationship between the spectator-viewer and the narrative elements revealed by the artworks' $(2010,74)$. By entering and exiting the interval, the visitor is given an opportunity to discover 'in himself the dual hypostasis of witness and participant' $(2010,73)$ and to engage in a personal reading and understanding of the fictional reality presented by the stage design of the exhibition. The specific goal of the installation is to produce a new agent, 'a new author, an author with a creative potential, a participant in the life of the exhibition: the spectator' $(2010,71)$.

What I find remarkable about the Romanian art project is that, programmatically, it represents a series of recent artistic explorations that employ the concept of the interval as 

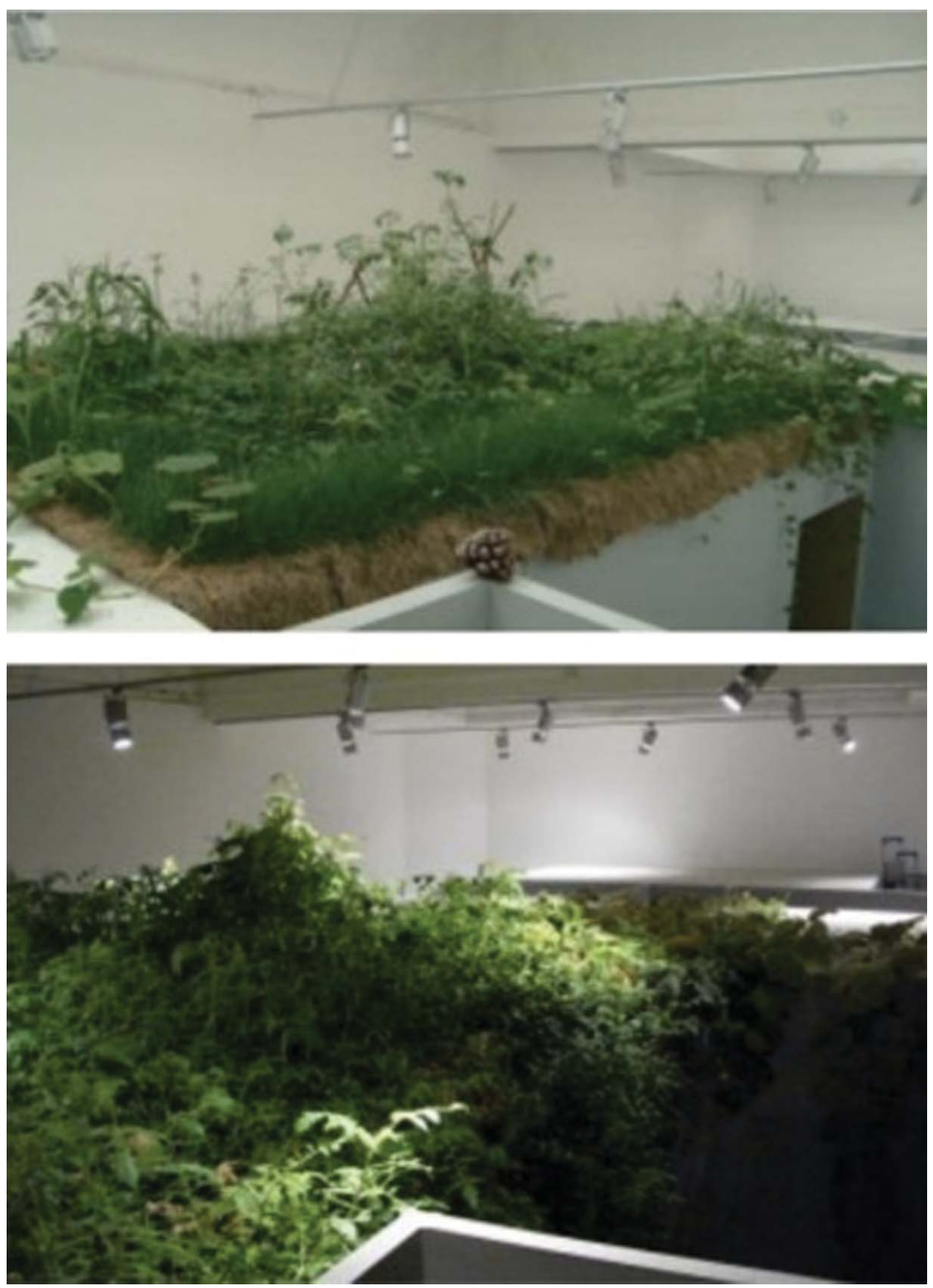

Figure 1. Installation The Seductiveness of the Interval seen from the outside.

a mode of understanding. ' 'Interval' is a complex term that is hard to grasp, since it has played a role in a variety of discourses and disciplines, yet, with some rare exceptions (as in music theory or Dziga Vertov's montage theory), has not been discussed comprehensively. Its etymology goes back to Roman times, with the interval originally referring to 
the space between two palisades (vallum in Latin). This spatial-physical meaning is also reflected in the word's use in Roman military architecture, where intervallum designated a path that - as an alternative to two parallel paths - lead directly into the heart of a camp secured by fortification walls (Kluge 2012; Ginouvès 1998, 31). In Greek, however, the term was employed less in a spatial than an abstract sense, as a temporal interstice that could be experienced metaphysically (Blyth 2010, 85). Based on the current meaning of 'interval', namely a break or interruption, the installation in the Romanian pavilion can be understood as a 'generation's need for interval and gradation, an attempt to stop the tempo', (Constantinescu, Faciu, and Mureşan 2010, 7), meant to offer the spectator new perspectives from within a transformative pause. The increasing use of the interval in East-Central European film and other visual art makes it impossible not to see its aesthetic and media-theoretical function as an expression of a condition that manifests itself in post-communist societies (see Kranicz 2016). Thus, the interval needs to be analysed not just as a formal and narratological artistic device but also as a phenomenon requiring political and social contextualisation. Self-positioning in-between time and in-between space is employed to question the relation between past and present. More precisely, it is employed to scrutinise the 'closure of event history'. When does a transition begin? When does a social transformation end? And how can we visualise the transitional process itself? Perhaps - and this is the argument I would like to pursue here - the interval itself serves as an expression of a 'post-communist condition' (Galasiska and Galasiski 2010), providing a framework for a historical-discursive examination of the watershed year of 1989 as well as the events following the political system, which initiated a phase of structural, political and social transformations in Eastern European countries.

Based on the pioneering conceptual approach presented in the installation The Seductiveness of the Interval, I would like to examine how Porumboiu's The Second Game and Popivoda's 3-channel installation Mass Ornament \#1 also confront the spectator with 'intervals of void spaces and intervals of time, in which nothing apparently happens, and which are left to the viewer to engage with and interpret' (Duculescu 2010, 79). In both works, not only is the spectator situated between different media constellations, that is, in a technological and perceptual interval; in addition - and this is my second thesis - the interval fulfils an aesthetic-epistemological function. Porumboiu and Popivoda use artistic self-positioning in an interval to enable both an intense cross-generational dialogue and an examination of the intertwined relationship between personal and national history.

\section{Long takes and nothing happens: Corneliu Porumboiu's film The Second Game}

The Second Game (2014) is Corneliu Porumboiu's (b. 1975) most unusual film project to date, falling between the worlds of cinema and art with its experimental approach. One of the key exponents of Romanian New Wave Cinema (Pop 2014, 7-41), Porumboiu's hitherto biggest successes were the feature films $A$ fost sau $n$-a fost/12:08 East of Bucharest (2006) and Politist, adjectiv/Police, Adjective (2009) (Bardan 2012). The Second Game, which stands out with its semi-documentary and autobiographic character, premiered at the Berlinale Forum in 2014. The following year, it was presented at the Kunstverein München, among other venues, in the context of a visual arts exhibition. The film is based on the archived television broadcast of a football match between the teams Steaua 
București and Dinamo București, which took place under heavy snowfall in Bucharest, on 3 December 1988. The eternal derby - as the regular confrontation between the two clubs was called at the time - taped on Video Home System (VHS), is shown in its entirety but without sound. ${ }^{3}$ Steaua and Dinamo were not just athletic but also political adversaries: the club of the army vs. the club of the secret police, popularly known as the Securitate. ${ }^{4}$ Dictator Nicolae Ceaușescu clearly favoured Steaua București, which had been put together by his son Valentin Ceaușescu. Twenty-five years later, filmmaker Corneliu Porumboiu and his father, Adrian Porumboiu, watched the match, in which his father had played an important role: He had served as the game's referee (Figure 2). During the replay of the taped match, we see neither the director nor his father. Instead, they provide an off-camera commentary on the on-screen action that they and we (as spectators of the same recording) are watching. Adrian Porumboiu talks about how he was under a lot of pressure at the time, which made it very difficult for him to act impartially. Both sides had tried to intimidate and bribe him prior to the match. Once, in a threatening phone call, young Corneliu, who had happened to pick up the phone, was told that he would never see his father again if he refereed the match badly. For Corneliu Porumboiu, this fear, which he would experience during all of his father's football matches in the following years, was his main reason for making the film. It was while watching the Romanian TV show Replay that he saw clips from a football match his father had refereed. He asked the show's producer, Marian Olaianos, for a copy of the broadcast and then asked his father

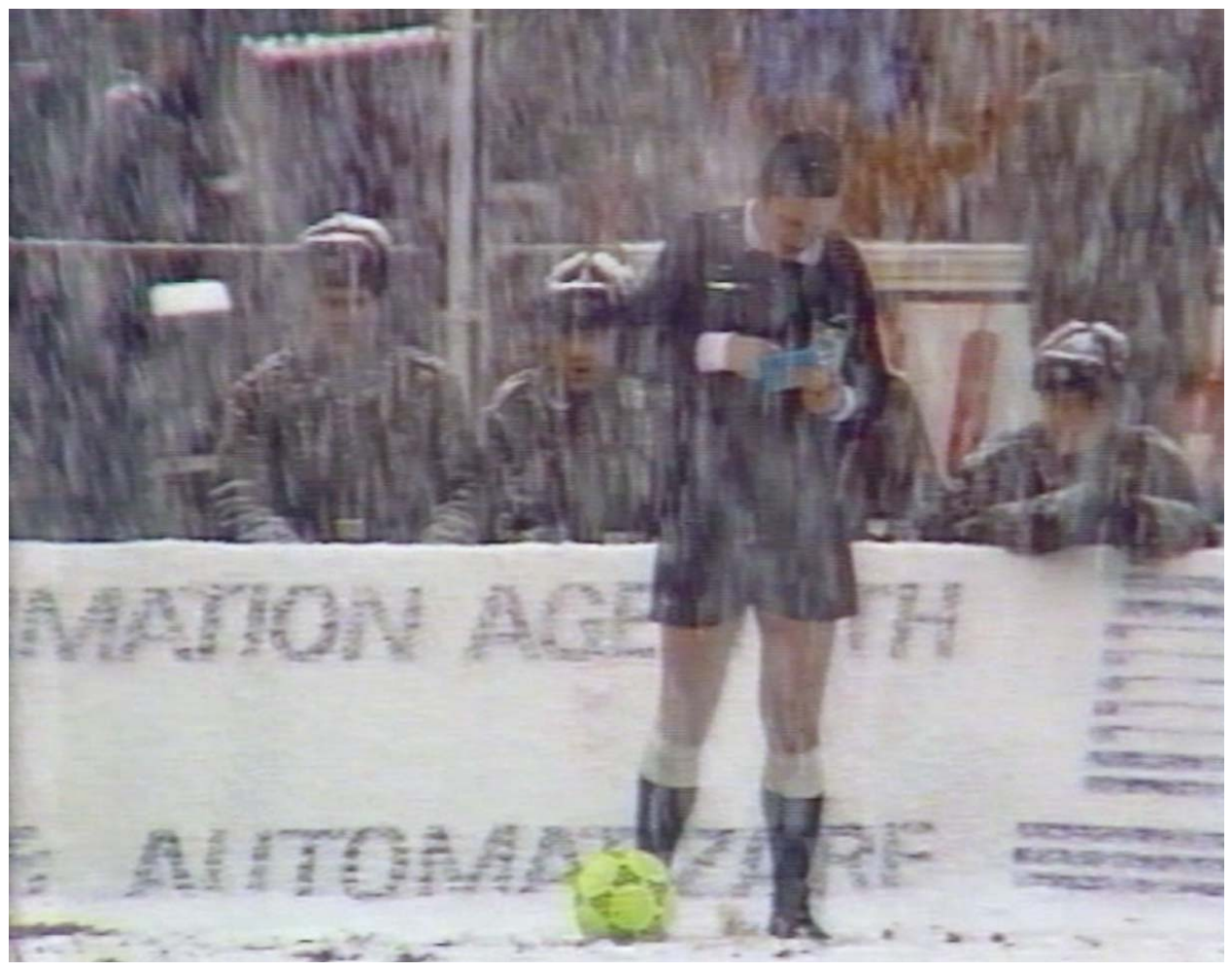

Figure 2. Adrian Porumboiu as referee in The Second Game. 
to join him in watching it. It was not until their fourth attempt that Porumboiu and his father succeeded in watching and recording the entire match without technical problems. Thus, they made three recordings of their conversation up to the 60th minute, but only one of the remaining playtimes (Filippi and Rus 2014).

What is interesting is the place from which Corneliu and Adrian Porumboiu's offscreen voices are heard. They are situated between the image space and the space of 'action', that is, between the screen projection and the TV screen. Their position is defined by an intermedia inter-vallum which provides the basis for an anachronistic mode of reception: They neither share in the present of the spectators in the stands in 1988 (Figure 3) nor in that of the current spectators in front of the projection screen. The interval already appeared as a concept in Porumboiu's previous film made in 2013. Before settling on the final title, Când se lasã seara peste Bucuresti sau metabolism/When night falls on Bucharest or Metabolism, he announced the film as A 9-minute Interval (Lavallee 2013). This suggests that the film's separate units, its chapter-like editing structure, were determined at an early stage of the film's conceptual design and were motivated by the guiding theme of the interval, in the sense of a movement to be complemented between shots. Apart from these formal aspects, the focus of The Second Game - similar to Porumboiu's famous earlier film 12:08 East of Bucharest - is on the intertwining of the power of images and a politicised coping with the past. According to the director himself, he wanted to

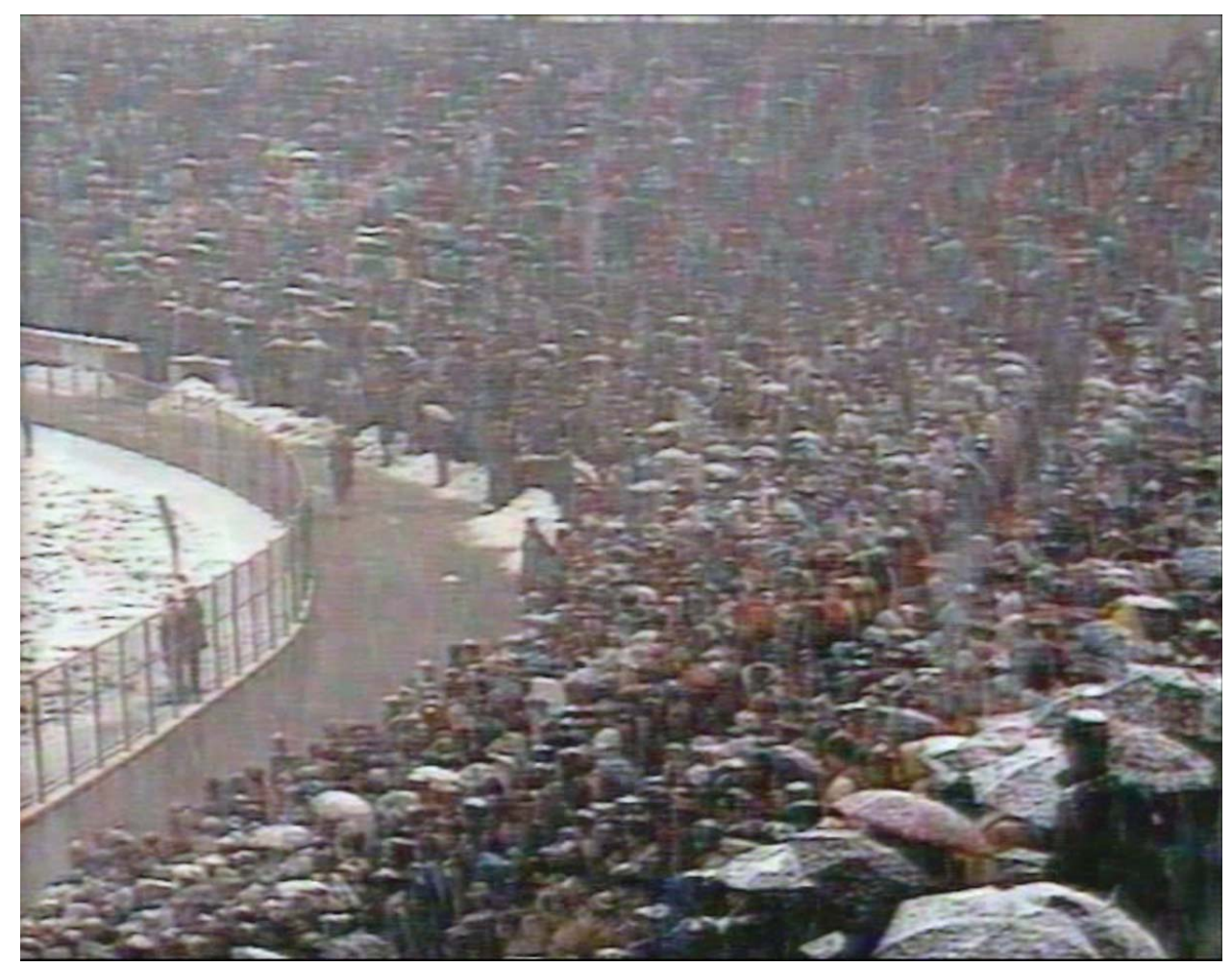

Figure 3. Spectators on the stands in The Second Game. 
take a political approach and 'Al doilea joc' has this, albeit not explicitly. While before 1989 we could have talked about censorship, because the camera was positioned in such a way at matches as to rarely catch a close-up of the players, and the conflicts between them were never shown, today there is a restrictive, albeit different way of broadcasting football games. The perspective the camera has now at matches is so precise, in the US tradition of extorting emotions by showing close-ups and re-runs, that the experience of watching the film in front of the TV has almost nothing to do with experiencing it live, at the stadium. Seeing again the match that my father refereed, I asked myself if this way of shooting with which I grew up isn't the one that indirectly shaped the way I relate to cinema. With my films I try to establish things, to ask questions, to recall certain events. Our society still has a black-and-white relationship with the past, a certain type of simplistic vision of history. I think this is one of the reasons I'm in cinema: to question this mentality. (quoted in Filippi and Rus 2014)

For this questioning, Porumboiu withdraws to a place that is simultaneously in front of and behind the camera, where he is simultaneously the subject and the object of the questioning. Here, the interval can be examined in a twofold manner: as a media-based interstice and as an aesthetic-epistemological approach to a retrospective understanding of history.

While it might seem odd to regular football fans today to watch the replay of a match, there is an unacknowledged reason behind it: the belief that by participating in real time, we can magically influence the course of the game (Pfaller 2007, 23). As media scholar Götz Grossklaus explains, with respect to live broadcasts, the real course of events, their observation and staging by the media, and the observation of this observation on the reception screen all concur in the same timeframe $(1999,7)$. A live broadcast simulates closeness by performing an 'erasure of the temporal interval in the broadcasting of images of the event' $(1999,8)$. It suggests to the audience that they are eye witnesses and it serves as a 'pleasurable levelling of symbolic difference and symbolic distance' $(1999,8)$. By making the edges of the cinema screen congruent with the TV format of the broadcast recording, The Second Game alludes to a media reality that is 'strictly presentic' $(1999,7)$, where the 'live media image of a football game' makes us forget that we are 'dealing with a filmaesthetically and technically highly mediated, artificial (iconic) sequence of signs' (1999, 8). However, Porumboiu deliberately undermines this perception by focusing neither on the one-time live experience nor on the match (the outcome of which, 0:0, is known anyway), but on the 'distance' to the event - the off-screen dialogue between father and son as they look at the events from a temporal and spatial distance. The formerly live media event of a football broadcast serves as a starting point for a retrospective recapitulation, reflection and reassessment of the circumstances of the time. Porumboiu achieves this in two different ways: first, through the use of VHS material that is filmed digitally and then presented in a cinema setting on a screen, and second, through its repeated disturbance by the commentators' vibrating mobile phones. Thus, history becomes readable as a history of media images, a history that has gone through a mainly technological transformation over the past 20 years. ${ }^{5}$ In addition to this media-technological perspective, the film offers a second reading, which points to the epistemological potential of a corrective commentary on a historic event, an event that occurred just a year before the violent revolution in Romania. In historic anticipation - or rather, in retrospect - the football field hosted an encounter between representatives of the two camps (secret police and army) that would topple Ceaușescu's regime in a bloody fight the following year. This possible reassessment of the historical-political circumstances - here applied to the basic 
circumstances of the game - is inscribed into the film's idea right from the beginning, because the original soundtrack has been removed and replaced by the dialogue between father and son. Shortly after the beginning of the second half of the match, an interfering noise from a mobile phone is heard, and the TV recording ends with an image interference, followed by the closing credits of the film.

These two moments of disruption in the context of a television broadcast are especially vital to Romanian history. Consider Nicolae Ceaușescu's last public speech given on 21 December 1989 in front of the Central Committee's building, where the situation among the crowd in front of the balcony escalated unexpectedly. A sudden faltering in the dictator's speech and the following image interference in the live broadcast gave some cause for concern and were seen as harbingers of the looming revolution. ${ }^{6}$ In this moment of interference, Ceaușescu's 'control over the image' was shattered, as Jean Paul Fargier puts it. More precisely, this happened because

the attackers had invaded the domain of the image - you could hear them on the soundtrack: for the first time in decades, a hyper-controlled TV broadcast featured hostile shouts instead of the official, more or less spontaneous, pre-recorded applause. And that alone was enough to crush Ceaușescu's power. To dethrone him. It was successful, this frozen image, like a goal in football crowning a well-played attack. It must be pointed out that Ceaussescu had been beaten by a sound effect. (1990, 94-95, emphasis in original)

Ceaușescu's opponents, but arguably also all the nameless and politically voiceless individuals assembled that day, suddenly managed to 'shove themselves into his image with their voices', thus making 'this image not his anymore', not 'his alone', as Fargier adds $(1990,94)$. In The Second Game, the context is more profane, but the basic premise is the same, when a formerly highly politicised football duel, once broadcast on state television, receives a new commentary after three decades.

While watching the replay of the game, Corneliu Porumboiu asks his father again and again - with almost childlike curiosity - about the reasons for his decisions on the field: why he blows for a foul or not, how he justifies his decision to let the teams 'play on advantage', how the rules of football have changed in the meantime and why the camera pans to the audience, sitting in the cold, as soon as a dispute arises on the field (Adrian Porumboiu: 'Because there is no disagreement among communists'). Or, Corneliu tries to aesthetically reinterpret the bad recording quality of the archival material, which, according to his father, seems to be 'from the stone age': Corneliu Porumboiu: 'I like the snow, it has a certain poetry...' - Adrian Porumboiu: 'There's no poetry here. What poetry is there in a football pitch like a farmer's field?' Or, Corneliu Porumboiu: 'I like it. It's a beautiful match'. - Adrian Porumboiu: 'There is no beauty in it, besides the player's tenacity'. At some points, their comments relate to one another like thesis and anti-thesis, as Adrian Porumboiu's answers reveal a more sober, sceptical view while looking at this piece of mediated past. From his perspective, there is neither poetry nor beauty in the match. Instead, Adrian Porumboiu never gets tired of repeating that these things are history now: 'They're not interesting to anyone. Just like this match isn't really of interest to anyone. Nobody cares how many Steaua-Dinamo matches there were. Time passes, things change, it's always moving forward... [pause]. Foul'.

The at times comical dialogue between the two notably subsides in the second half of the film, leading to Corneliu Porumboiu's self-ironic comment that the match looks like 
one of his films - long takes and nothing happens. The father's repeated comment that nobody would want to see this kind of thing nowadays does not just reveal his fatherly lack of understanding for the film project's artistic value. In addition, it involves the spectator in front of the screen. And this spectator might indeed wonder why Corneliu Porumboiu had to make a film in order to have his questions answered. But a different question might be more illuminating: Why did he have to first construct such an interval in order to ask questions about the historical past?

\section{The interval - historical and philosophical contexts}

While the notion of the interval is established in a film theory and media studies context, where it refers to various reception modes based on technological conditions, ${ }^{7}$ there have also been attempts to make the interval productive in philosophical, life-related and epistemological contexts. Among the first texts in this respect is the 1933 essay La cause et l'intervalle, ou Ordre et probabilité by Belgian philosopher Eugène Dupréel, in which he critiques overly simple and linear concepts of causality and determinism. In his line of reasoning, the interval is defined as a constitutive element in the distinction between a cause and an effect. Instead of a seamless sequence, Dupréel sees a necessary aspect of 'discontinuity' in the interval, an important step of 'difference' between a preceding cause and its subsequent effect. Without this intermediate level (chose d'intercalaire) - whether defined in a temporal, spatial or structural way - it would not be possible to distinguish the two events (Dupréel 1949, 200-201). Dupréel aims at a philosophy that can be applied to all ways of life and phenomena of the everyday (1949, 196-197). Intervals go hand in hand with events, and they structure the way we experience things. At the same time, we can infer a critical questioning of isolated changes and turning points from Dupréel's argument, as he introduces a spatial-temporal shift. To be perceived as distinguishable and singular, each event is framed by an interval before and after it. This interval is also the place where an unexpected deviation can occur, where a new possibility can influence the further course of events. A cause never touches its effect directly. Rather, it is contiguous to a composite intermediate reality (réalité intermédiare et composite [1949, 201]). In his philosophical essay, Dupréel anticipates functional forms of the interval, which were taken up in French philosophy in the 1960s, yet never embedded in a comprehensive theory. Thus, the interval appears in Maurice Blanchot's work within the semantic field of interruption and pause $(2010,171)$, while Emmanuel Levinas and Jacques Derrida use it in the context of separation and difference (Libertson 1982, 190; Derrida 2009). In its purely epistemological function, the interval is notably described by French art scholar Georges Didi-Huberman. In his writings on Aby Warburg, the interval refers to the interstice in which the Nachleben of events, of the past, occurs. Especially the experience of polarities and contradictions leads to 'processes which occur in the intervals and in which one can detect the passage, or the possible conversion of one order of reality into another' (Didi-Huberman 2017, 329-330, emphasis in original). Here, the interstice operates as a kind of 'epistemological tool', because our 'memory is an excellent assembler [monteuse]: it arranges heterogeneous elements ("details"); it creates faults in the continuum of history ("intervals") in order to open up new pathways; and it plays with - and works with - the intervals between fields'. (2017, 329, emphasis in original). In this sense, interpretation and the attribution of meaning also belong to the category of the interval, since they 
operate in the "zone "between two meanings"' $(2017,331)$. All these various accentuations of the interval are not mutually exclusive, but serve to highlight the manifold spheres of influence in which the interval structures our experiences in speaking, thinking, perceiving and understanding. Most importantly, the interval is where transition and approximation take place; where time periods (whether experienced, remembered or imagined) overlap to the point where it becomes impossible to differentiate between progress and standstill.

Porumboiu's film The Second Game attempts to approach a historical before-and-after from an intervallic situation in the Dupréelian sense, with the event of the revolution itself forming the gap, the historical ground zero around which everything revolves. Corneliu and Adrian Porumboiu occupy the position of 'spectators in the interval', relating to the stadium crowd of 1988 and looking (forward and back) at the events with a new and different understanding of the events. However, this metahistorical approach, intended to give the two spectators room for a true reassessment, never quite gets off the ground due to the inherent limitations. There is a crucial catch to this filmic experiment: Corneliu Porumboiu and his father are 'part of the image' that they want to observe from a distance. And it is precisely because they are caught in the interstice of the image - partly as voices, partly as observed bodies - that their change of position is less radical and obvious. A comparison with Marta Popivoda's spatial installation might bring to light revealing parallels in the experimental set-up. Here too, a highly symbolic sporting event from the socialist era serves as the basis for a discursive, simultaneously repetitive and transformative examination. In the case of Popivoda's film, however, the installation's set-up is already directed towards a change of attitude and assigns the spectator a greater share of responsibility.

\section{I spy with my little eye...: socialist mass ornaments and the performance of rupture}

The creation of the 3-channel installation Mass Ornament \#1 (Watch out for gorillas in your midst!) is closely linked to the found footage film Jugoslavija, kako je ideologija pokretala naše kolektivno telo/Yugoslavia, How Ideology Moved Our Collective Body (62 min.), which was released the same year, 2013, by Serbian filmmaker and video artist Marta Popivoda (b. 1982). Both works were developed in cooperation with the visual art theorist and curator Ana Vujanović. For the film Yugoslavia, How Ideology Moved Our Collective Body, Popivoda and Vujanović thoroughly studied archived television footage that had been broadcast on Yugoslav TV (and later, in post-socialist Serbia) between 1945 and 2000. Their main focus was television broadcasts of socialist mass celebrations in public spaces (May Day parades or celebrations in honour of youth) as well as footage of street demonstrations (such as the uprisings of 1968 and the student and civil rights movements of the 1990s). Edited in chronological order, the film traces the occupation of public space from the Yugoslav post-war period to the early 2000s in Belgrade in an essayistic manner. The film is the result of the joint project Performance and the Public (2011-2012), which Popivoda developed together with Bojana Cvejić and Vujanović. All three are members of the collective TkH-Walking Theory (teorija koja hoda in Serbian), which was founded in Belgrade in 2000 by Vujanović and Cvejić, among others. The collective - composed of members from the fields of art theory, film, video, theatre and performance - sees itself as 
a platform for performative, critical and theoretical-artistic activism (Popović 2015). Marta Popivoda herself is part of Belgrade's independent, leftist, cultural-artistic scene, which currently faces numerous structural challenges. In her documentary Cultural Worker 3 in 1 (2013), Popivoda addresses these cultural-political and cross-border problems in the post-Yugoslav context. Her documentary essay Yugoslavia, How Ideology Moved Our Collective Body not only enjoyed great success at festivals but also evoked harsh criticism for its highly subjective and one-sided perspective on Yugoslav socialism and its very ambivalent relationship to communist ideology. The film contains images of the ideologically charged mass parades (emblems of governmental order) which are juxtaposed with the un-choreographed, chaotic movements of demonstrators. In the course of their research, Popivoda and Vujanović came across footage of the socialist Youth Day Celebration (Dan mladosti, or slet)) of 1987, an elaborate mass performance at Belgrade's JNA stadium (Stadium of the Yugoslav National Army), which had been held annually, in honour of Tito's birthday, on 25 May since 1957 (Figure 4). It was preceded by a ceremonial relay race, in which the so-called relay baton of youth (stafeta mladosti) was carried from the north-western to the south-eastern end of the country, across six republics and two provinces (štafeta mladosti had been the name of this festivity from 1945 until 1957, when Tito changed it to Dan mladosti). The climax of the event was the moment when a chosen runner (usually an excellent student) handed the relay baton to Tito at the stadium (Cvejić and Vujanović 2012; Vujanović 2012). ${ }^{8}$ Mass parades have fulfilled a variety of ideological functions over the course of their history, yet they all have certain aspects in common: In addition to serving as an homage to the mentally and physically healthy

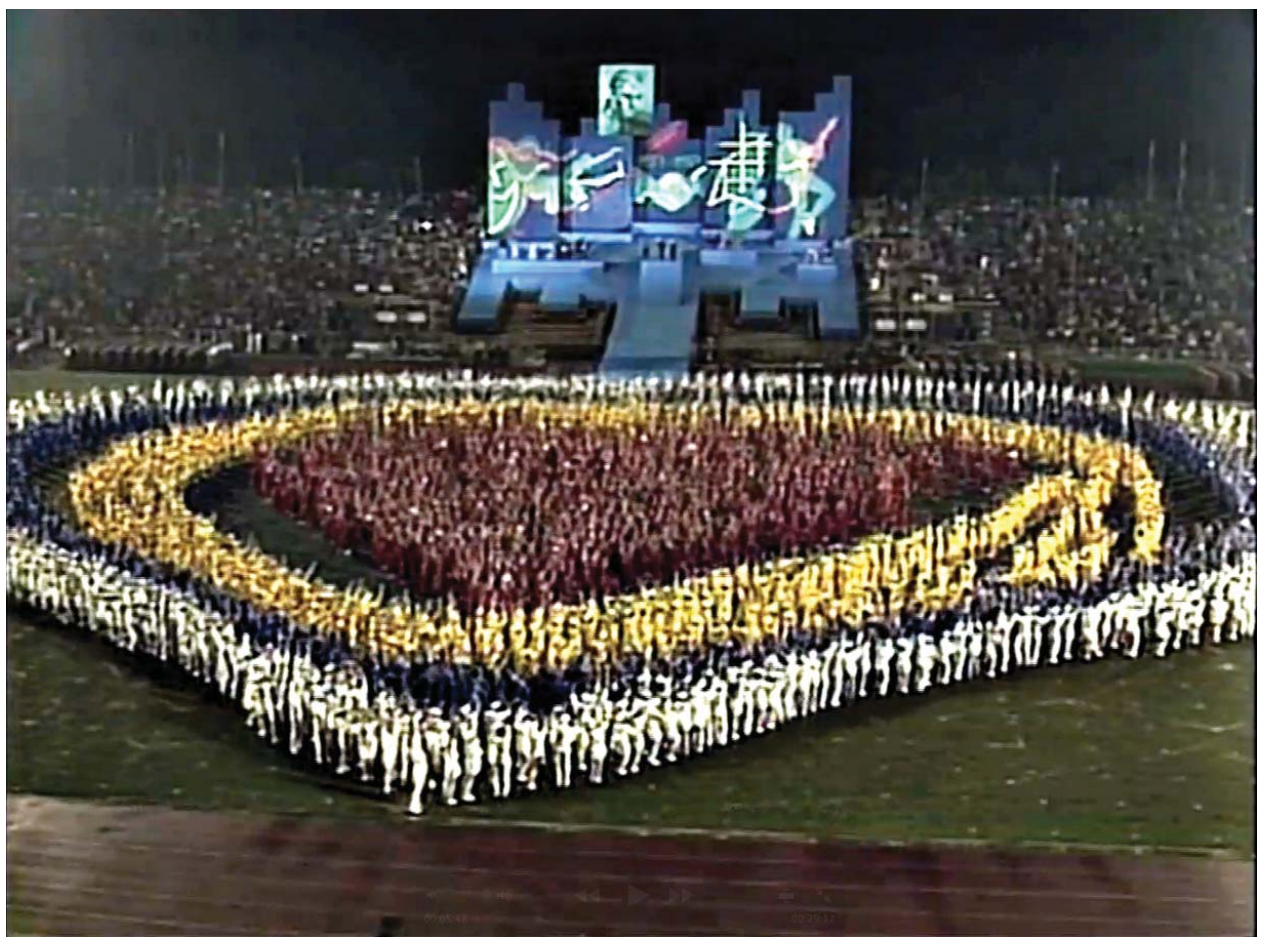

Figure 4. Video still from Mass Ornament \#1. 
human being as an embodiment of social change, they all share the ideas of collectivism and egalitarianism and an awareness of the aesthetic aspect of ideology (Vujanović 2013). The socialist Youth Day Celebration, with its normative and repetitive character, demonstrated how ideology was literally inscribed into people's bodies. Those bodies in turn served as visual representation of a superficial national unity, which, subsequently, would also become the site of an emerging rupture. In retrospect, the 1987 Youth Day Celebration, with its homage to international unity and brotherhood, turned out to be a delicate undertaking, as it occurred at a time close to a political turning point: Only two years later, the Berlin wall would fall, and the socialist state of Yugoslavia would fall apart with the outbreak of the wars of independence. While viewing the footage of the choreography, Popivoda and Vujanović, to their surprise, discovered 'striking signs of the imminent collapse of the country which spectators seemingly didn't "see"' (Popivoda; cited from the artist's website). They isolated the respective sequence from the footage and used it to create their 3-channel installation Mass Ornament \#1 (Watch out for gorillas in your midst!). In the following, I would like to discuss the installation in more detail, as it goes one step further than Popivoda's previously mentioned documentary essay. Basically, the installation complements Popivoda's personal reading of Yugoslav history by introducing a more discursive approach and by filling an important gap. At one point in Yugoslavia, How Ideology Moved Our Collective Body, the narrating voice notes that:

[it] happens so quickly that I always fail to notice the moment of change. Again. In one moment there was the socialist choreography collapsing. In the next citizens sobered up and started to believe that they were free and independent individuals, in the next, they slaughtered, robbed and devastated all they had built up together. History gives a clear answer. But I don't. I am asking questions. Staring at the theatre.

Instead of pursuing the ideological developments in Yugoslavia and Serbia, respectively, throughout the political shift of power in the 1990s, the emphasis in the installation lies on the moment that was omitted in the film: the moment of rupture, the moment that anticipated political change.

\section{Dancing gorillas in the choreographic subconscious: Marta Popivoda's treatment of the historical past in Mass Ornament \#1}

In their video installation, Popivoda and Vujanović create a complex viewing situation, spanning time and media, a situation that is not as explicit in Porumboiu's The Second Game. Nevertheless, there are certain obvious parallels and connections between the two works. Similar to Porumboiu's film, the ideal protagonist in Mass Ornament \#1 is positioned as a 'second-order' spectator between media spectacle, socio-political analysis and scientific objectivity, which is provided by the spatial constellation.

The installation (Figure 5) consists of three parts (two TV screens, a video projection and an audio recording), which are played back in staggered order. The spectator takes a seat in the middle of the room, in a row of chairs in front of the cinema screen. Before the video footage is projected onto the big screen, two TV screens - positioned on the floor to the side of the chairs - show newsreel footage: While one TV screen shows broadcast recordings of the parade from 1987, the other features news material about the sociopolitical events that preceded and followed it (among other things, the initially planned 


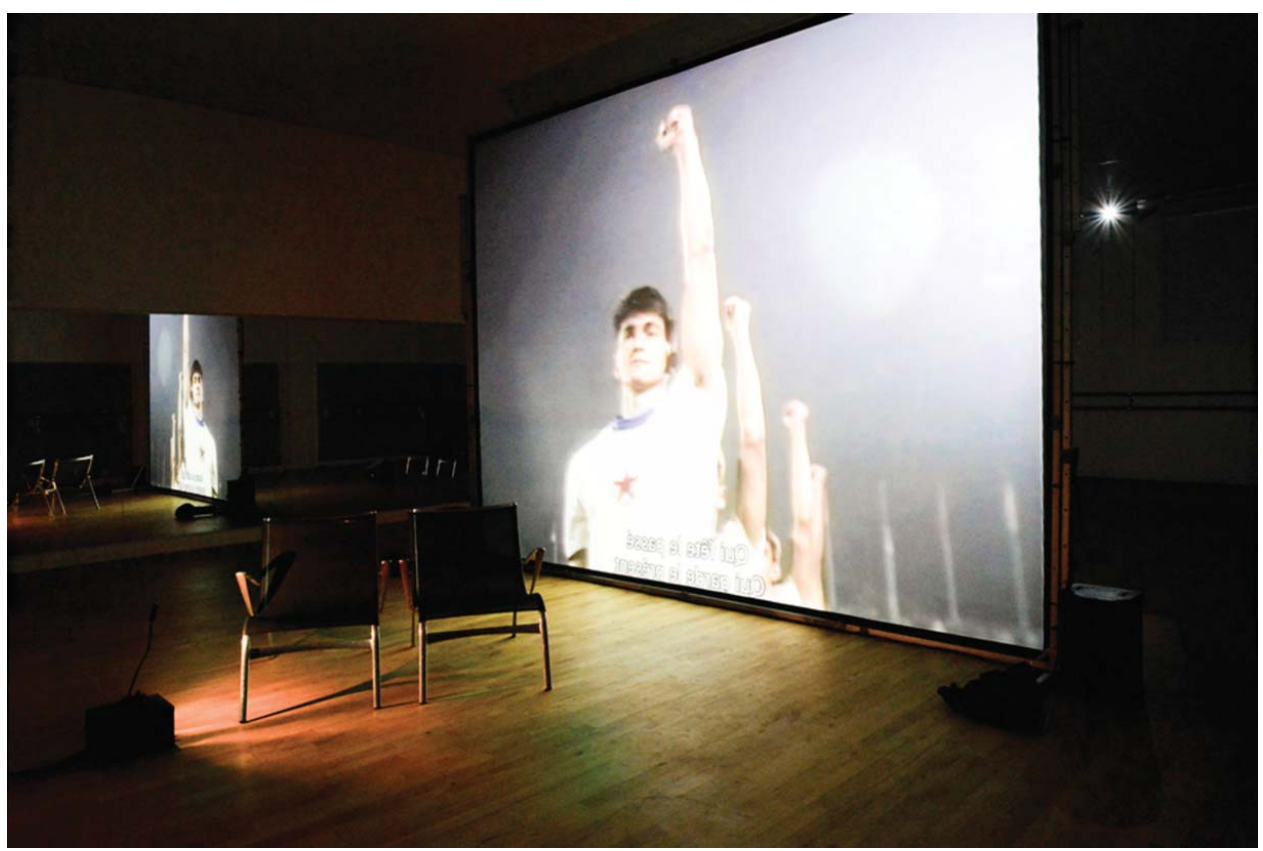

Figure 5. Display of Mass Ornament \#1 by Marta Popivoda and Ana Vujanović.

poster for the slet sparked a party-political conflict). When the video projection in front of the spectator ends, an audio recording is played from a speaker located behind them, in which the psychological phenomenon of inattentional blindness is explained.

The 20-minute found-footage sequence, which is embedded between the two other parts, is divided into four chapters ('Freedom didn't come out of the blue', 'The rise and fall of the working class', 'The anti-bureaucratic revolution' and 'The last five-year plan'), showing scenes from the stadium. In top shots of a choreographed dance performed on the stadium field, the young dancers' varying costumes point to the fact that all social levels are represented (among others, craftsmen, soldiers, professionals, students and farmers). The top shots alternate with medium long shots of the dancers and cutaways to the government officials, who silently watch the slet from their box seats. Patriotic folk songs, singing the praises of unity, peace and brotherhood among comrades, are heard from the stadium speakers. Time and again, the camera captures the spectators in the stands, who are captivated by the performance (Figure 6). The surprise experienced by Vujanović and Popivoda as they were viewing the footage after 25 years also overtook the two commentators, who, at the time, were broadcasting the event for the TV audience. As the dancers in the stadium are about to form the Kolo, a traditional Yugoslav round dance, the two commentators suddenly notice an unexpected twist:

Commentator 1: As you can see, the round dance started off harmoniously. [pause] But there's something going on.

Commentator 2: So what happened to the harmonious round dance from the beginning? Why are the groups, one by one, slowly drifting apart? 


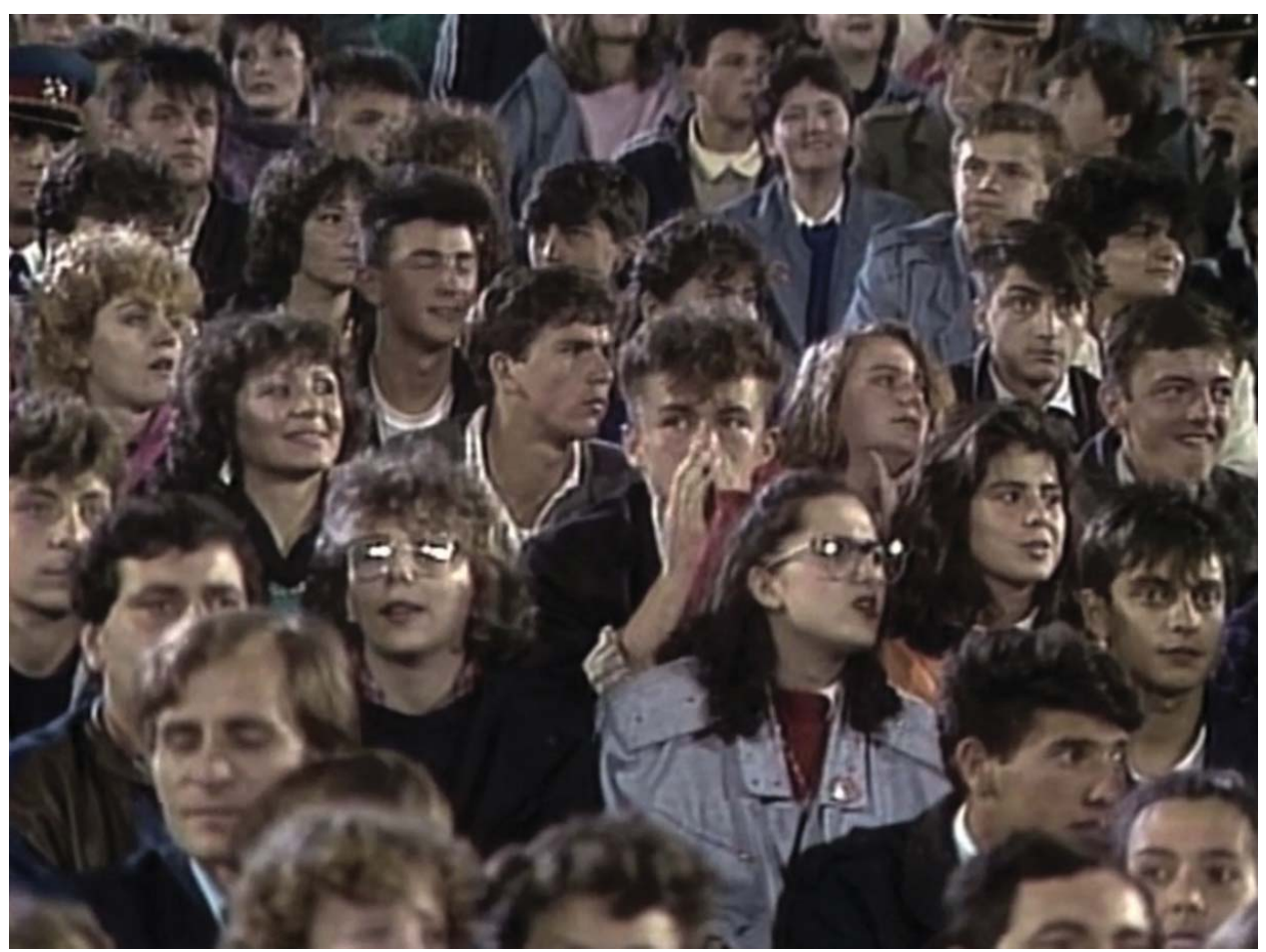

Figure 6. Video still from Mass Ornament \#1: Spectators at the slet.

Commentator 1: Serbia is dancing by itself now, and now Croatia, and Bosnia-Herzegovina... One by one, the republics and the provinces are drifting apart.

Commentator 2: Why are we dancing in eight different groups? Why are we dancing... Why are they dancing to their well-known folk melodies, but not together?

Commentator 1: It seems we're not as united as we should be... [pause] We interpret this as a warning. A lively and tuneful warning, yes. But even if everything seems fine on the outside, inside, we're struggling with eight different staves and such a score is hard to perform in harmony.

Commentator 2: This dance is warning us about the current situation.

The last image of the performance shows eight closed circles. The following sequence in the found-footage video shows another choreographed dance, but this time it is a military performance in which young men march with rifles in their hands. The song lyrics sounding from the speakers state 'We are the soldiers of the sun, healthy, strong and young, we are the army of peace'.

Within the constant ordering and reordering of the parade, an interval suddenly opened up, in which the choreographic ornament - in the sense of Siegfried Kracauer's programmatic and eponymous text The Mass Ornament from 1927 (1975) - took on a life of its own: performing a disintegration. The 'drifting apart of the symbolic states' during the parade - recorded by the TV cameras, seen/unseen by the spectators, commented on by the moderators - is perhaps one of the few visible moments of a historic turning point, the kind that usually eludes retrospective access. Ana Vujanović describes it as an 
'embodiment of a choreographic subconscious' (2013, 22), which becomes even more obvious the following year, when the collectivism of the performance is replaced with an individual dance by Sonja Vukičević; 1988 would be the last year the Youth Day Celebration would be held. In Mass Ornament \#1, this brief moment of prefigured disintegration thus becomes a test object for an understanding that runs asynchronously to historical reality. To put it more explicitly: Remarkable is not so much the resulting 'image' of the eight closed circles but the brief processual moment in which 'the framing' of this new image emerged.

Right after the question of why the stadium visitors and the TV audience at the time had not seen those signs, the video footage on the screen is replaced by an audio track of a report concerning a study on inattentional blindness. The term 'inattentional blindness' was coined by psychologists Arien Mack and Irvin Rock in their eponymous study published in 1998. It designates the inability to notice a clearly visible but unexpected object when one's attention is simultaneously directed at another object, event or task. Two years later, Daniel J. Simons and Christopher F. Chabris published their study Gorillas in our midst: Sustained inattentional blindness for dynamic events (1999) and went a step further, examining so-called change blindness in addition to inattentional blindness. Among other things, the two psychologists observed the phenomenon of city dwellers who were capable of overlooking a passerby in a gorilla costume (1999, 1066-1067). During their repeated viewings of the slet, Popivoda and Vujanović discovered numerous political hints and warnings, whose fatal ineffectiveness only reveals itself in historical hindsight. Thus, the aphorisms projected on monitors in the stadium and read aloud by the TV commentators for the viewers at home contained a kind of prescient urgency, which, however, was only partially seized on by the commentators reading them: 'The message on the display says: Every nationalism is equally dangerous, even ours'. 'Hey Dragana, take a look at the screen; there's a great aphorism for you: Everything is ephemeral, only consequences endure'. Alluding to the study by Simonis and Chabris, from which they derived their artistic premise, Popivoda and Vujanović, 'caution' spectators, in the subtitles, to watch the parade attentively:

Bearing in mind the future to which the slet in 1987 acted as past, we take the blind spectators as the video's main protagonist. They are the ones who embody and at the same time fail to see the macro image of society and history, either because of being preoccupied with the ordinary trifles of everyday life or because the image is hidden by its obviousness (Popivoda; cited from the artist's website).

While the video projection has an absorbing effect, the installation's other two elements serve as a means of distancing and historical contextualisation. In Mass Ornament \#1, the spectator of the installation itself is positioned between the (two) TV screens and the cinema screen, a position that transcends the various media constellations. Standing/sitting within the interval, the spectator is in turn confronted with a performed interval. With this diachronic method, Popivoda wants to:

open a dialogue between the disembodied spectator of the slet and a bodily present spectator of our video. By disembodying those whose bodies were literally violated, harmed, or destroyed during the wars, we attempt to displace the focal point from the screen to the live bodies of spectators of the video, in order to point out their own historicity (Popivoda; cited from the artist's website). 
Through the recurring cutaways to the stadium stands, the spectator of the installation is forced to position themselves not just in a historical before-and-after, but also in an epistemological sense. The reaction Popivoda ideally wants to elicit with her spatial constellation is for the spectator to turn their head after the conclusion of the video projection in order to listen to the audio recording on inattentional blindness coming from behind. The aim of this physical turn is to trigger an epistemological turn, a moment of awareness and historical responsibility, in which the spectator recognises themselves in a double role of witness and participant.

In his reflections on communism itself, Boris Groys' describes it as 'an interruption, interval or delay in the continuous "normal" development of East European countries - a delay which, once it was over, left no traces other than a certain appetite to "make up for lost time"' (2009). In light of this, it might seem reasonable to reappropriate the idea of communism retrospectively through a corresponding aesthetic concept, namely the interval, in order to deal with it as a historical reality. Only after it concluded did the communist vision - which once lay in the future - become 'a definitive historical reality', whereby '[c]oncluded...naturally does not mean exhausted, obsolete, superseded or proven impossible; what it does mean, among other things and in particular, is that it is released for historical repetition' (Groys 2009). It may well be that Popivoda's underlying questions (Why didn't people continue to fight for the Yugoslav socialist experiment? What marked the beginning of the end of Yugoslavia?) appear incomprehensible to some, as Popivoda herself acknowledges (Popović 2015). ${ }^{9}$ Her questioning of Yugoslav socialism, its ideological manifestation in social choreographies, may irritate precisely because it is situated between affirmation and negation of the communist experiment; it may irritate because it scrutinises the distinction between utopia (the communism of the past) and anti-utopia (the today's neoliberal capitalism). Still, if the interval is 'the abyss that the historian must agree to examine' (Didi-Huberman 2017, 332), this task also applies to a new generation and their desire to take their own stand, to define their own position towards the historical past, and their search for a personal mode of understanding.

\section{Conclusion: at the crossroads of the past and the future}

It goes without saying that the parallels in the artistic methods applied in The Second Game and Mass Ornament \#1 do not amount to a systemic parallel between the postcommunist social conditions in Romania and those in the former Yugoslav states (especially given that the last of the bloody conflicts in the Yugoslav wars of independence continued until 2001). Yet, despite all their differences, the two works point to the still necessary and ongoing coming-to-terms with this historic phase of transformation. The works' approach via a transgressive spatial and temporal figure raises the question of whether the interval - with the performative quality it has here - could also be interpreted as a geopoetical means of representation. If geopoetical is understood as describing a 'strategy of self-positioning that answers to the process of systemic transformation, such as the change of East Central Europe's political geography' (Marzałek and Sasse 2010, 13; White 1987), then the interval offers an instructive concept with which to simultaneously mark and deterritorialise boundaries. At the same time, it provides an alternative or supplementary approach to post-colonial readings of current feature films, such as Szabolcs 
Hajdu's Bibliothèque Pascal (2010) and Ágnes Kocsi's Friss levegö/Fresh Air (2006), which employ notions of the interval and in-betweenness in their fictional narratives (see Pieldner 2016; Virginás 2016; Mazierska 2010, 11).

Two main premises of the Romanian installation The Seductiveness of the Interval also characterise the basic premise of the works by Porumboiu and Popivoda discussed here: Both create a spatial interval, which can be physically occupied by the spectator, who is then faced with the task of becoming active as an interpreting, observing viewer. It is noteworthy that both The Second Game and Mass Ornament \#1 feature edited footage of ideologically charged sporting events, which, in their archived materiality, serve as historical memories. In doing so, the filmmakers articulate their struggle with competing images from their personal experiences, memories and official media. Furthermore, both works focus their attention not on the historically datable event of the political turn but on a phase shortly before. Though they were produced well after the transitional era of the 1990s, they introduce a historical shift from within the interval, which questions the precise 'datability' of a cause and its effect by emphasising the framing process of an ongoing phase of transition and transformation. With respect to the filmmakers' desire to shape the present, their aim corresponds with the statements of the young people in 1987, quoted by the newsreader on one of the two TV screens in Popivoda's installation: 'So at the crossroads of the past and the future, the youth marked their day with the following motto: "We want the present."

In their works, Popivoda and Porumboiu make it clear that a confrontation with the present entails the same responsibilities as a continuous examination of the past, which in turn is always a mediated one: consistently modified by new technologies, by new readings and comments. In particular, Porumboiu's father-son conversation reveals that a confrontation with the past starts by confronting a different generation with differing views on or interpretations of the same subject. If, in this dialogic arrangement, the interval is understood as a necessary interruption of the present, it is then exactly this interruption that 'makes the future possible; the discontinuity ensures the continuity of understanding' (Blanchot 2010, 172). Positioning oneself in-between time and in-between space both offers protection and gives authorisation to approach that which cannot be integrated into the narrative of historical continuity.

\section{Notes}

1. The following works were shown: Ştefan Constantinescu, Passages, 62 min., 2005; Troleibuzul 92, RED transferred to Blu-ray, 8 min., 2009; Andrea Faciu, EXUBERANTIA suspended, mixed media installation, 2009; Ciprian Muresan, Dog Luv, video, 30 min. 25 sec., 2009; Ciprian Muresan Auto-da-Fé, 3-channel-presentation, 154 slides, 2008.

2. In my doctoral thesis, the scope of my research also includes works of Ştefan Constantinescu, Iosef Kiraly, Ivana Franke and Nedko Solakov, among others.

3. Quoted from the accompanying brochure for the film screenings at the Kunstverein München, which took place from 28 May to 17 June 2016.

4. In the case of Dinamo, it only became clear after 1989 that the football team was controlled not only by the police (Ministry of Internal Affairs) but also by the Securitate.

5. See also Virilio's remarks on the so-called revolution of the broadcast media (which he also calls a 'critical transition'), and the term 'third interval' (1993). 
6. Various feature films and video works have used this occurrence, e.g. Catalin Mitulescu's Cum mi-am petrecut sfârsitul lumii/The way I spent the end of the world (2006) and Harun Farocki's and Andrei Ujica's film Videogramme einer Revolution/Videograms of a Revolution (1992).

7. The interval first appears as a key concept in Dziga Vertov's film-theoretical development of a 'theory of the interval' (1919/1922), in which the former music student describes his special montage technique emphasising the movement between shots (see Petric 1978, 35). See also the media-technological approach in Paul Virilio's texts (1993).

8. At the 1987 slet, the baton was passed to Hašim Redžepi, then president of the Young Communist League of Yugoslavia (Savez komunističke omladine Jugoslavije, SKOJ).

9. In an interview with Gordana Popović, Marta Popivoda was asked about her personal stand on socialist Yugoslavia: 'No one on our film crew lived in socialist Yugoslavia for a long time, which is why we don't know much about it from our own experience; still, we all grew up in this context and atmosphere. It was enough for us to know that there exists something completely different, an attempt to provide social equality. It is likely that many who experienced Yugoslav socialism over a longer period won't agree with us, but I think that it is precisely our distance to it that offers us a critical and macro perspective, an opportunity to look at it from within the context of the present moment as well as other social-political options of that time' (Popović 2015).

\section{Disclosure statement}

No potential conflict of interest was reported by the author.

\section{Notes on contributor}

Patricia Pfeifer is a research assistant and doctoral student in the Department of Film Studies at the University of Zurich. Her research interests include visual studies and Eastern European contemporary art and film. She is currently writing her doctoral thesis on visual transformations in contemporary Eastern European film and art. She has published articles on Hungarian and Yugoslav cinemas.

\section{References}

Bardan, Alice. 2012. “Aftereffects of 1989: Corneliu Porumboiu's 12:08 East of Bucharest (2006) and Romanian Cinema." In A Companion to Eastern European Cinemas, edited by Anikó Imre, 125-147. Oxford: Wiley-Blackwell.

Berger, John. 1972. Ways of Seeing. London: BBC.

Blanchot, Maurice. 2010. Das Neutrale: Philosophische Schriften und Fragmente [The Neutral: Philosophical Writings and Fragments], edited by Marcus Coelen. Zurich, Berlin: Diaphanes.

Blyth, Alystair Ian. 2010. “An Introduction to the Interval: Notes Towards a Metaxylogy." In The Seductiveness of the Interval. Romanian Pavilion: 53rd International Art Exhibition, edited by Ştefan Constantinescu, Andrea Faciu, and Ciprian Mureşan, 83-86. Stockholm: Romanian Cultural Institute of Stockholm.

Constantinescu, Ştefan, Andrea Faciu, and Ciprian Mureşan. 2010. The Seductiveness of the Interval. Romanian Pavilion: 53rd International Art Exhibition. Stockholm: Romanian Cultural Institute of Stockholm.

Cvejić, Bojana, and Ana Vujanović. 2012. Public Sphere by Performance. Berlin: b_books.

Derrida, Jacques. (1982) 2009. Margins of Philosophy. Translated and edited by Alan Bass. 13th ed. Chicago, IL: The University of Chicago Press.

Didi-Huberman, Georges. 2017. The Surviving Image: Phantoms of Time and Time of Phantoms; Aby Warburg's History of Art. Translated by Harvey L. Mendelsohn. University Park: The Pennsylvania State University Press. 
Duculescu, Mirela. 2010. “Consuming Disruptive Worlds.” In The Seductiveness of the Interval. Romanian Pavilion: 53rd International Art Exhibition, edited by Ştefan Constantinescu, Andrea Faciu, and Ciprian Mureşan, 71-79. Stockholm: Romanian Cultural Institute of Stockholm.

Dupréel, Eugène. 1949. "La Cause et l'Intervalle ou Ordre et Probalitité." [The Cause and the Interval or Order and Probability.] In Essais pluralistes, edited by Eugène Dupréel, 196-235. Paris: Presses Universitaires de France.

Fargier, Jean Paul. 1990. “Geisel des Bildes - Bild der Geisel.” [Hostage of the Image - Images of the Hostage.] In Von der Bürokratie zur Telekratie: Rumänien im Fernsehen; Ein Symposion aus Budapest [The Media Are With Us!: The Role of Television in the Romanian Revolution], edited by Keiko Sei and Peter Weibel, 94-102. Berlin: Merve Verlag.

Filippi Gabriela, and Andrei Rus. 2014. Al doilea joc - The Second Game: Interview mit dem Regisseur. Arsenal: Institut für Film und Videokunst e.V. Accessed 26 March 2017. http://www.arse nal-berlin.de/distribution/news/einzelansicht/article/5011/2808.html

Galasiska, Aleksandra, and Dariusz Galasiski, eds. 2010. The Post-Communist Condition: Public and Private Discourses of Transformation. Amsterdam: Benjamins.

Ginouvès, René. 1998. Dictionnaire Méthodique de l'Architecture Grecque et Romaine. Vol. 3, Espaces Architecturaux, Bâtiments et Ensembles. Athens: Ecole Française d'Athènes.

Grossklaus, Götz. 1999. Medium und Intervall: Vom Buch zum Computer. Accessed 26 March 2017. http://www.boell-hessen.de/archivseite/pol/gros.htm

Groys, Boris. 2009. "Becoming Former West.” [The essay first appeared in: Hlavajova, Maria, and Jill Winder. 2004. Who if not we should at least try to Imagine the Future of all this?: 7 Episodes on (ex)Changing Europe. Amsterdam: Artimo.] Accessed 20 June 2017. http://becoming-former. tumblr.com/post/262880375/the-post-communist-condition-boris-groys-the

Kluge, Friedrich. 2012. Etymologisches Wörterbuch der deutschen Sprache. 25th ed. Berlin: de Gruyter.

Kracauer, Siegfried. 1975. “The Mass Ornament.” New German Critique 5: 67-76.

Kranicz, Bence. 2016. "Report in-between Worlds, in-between Images." Studies in Eastern European Cinema 7 (3): 293-295.

Lavallee, Eric. 2013. "2013 Cannes Film Festival Predictions: Corneliu Porumboiu's A Nine-MinuteInterval.” Ioncinema, April 13. Accessed October 26 2016. http://www.ioncinema.com/news/fes tival-predictions/2013-cannes-film-festival-predictions-corneliu-porumboiu-a-nine-minuteinterval

Libertson, Joseph. 1982. Proximity: Levinas, Blanchot, Bataille and Communication. Berlin: Springer Netherland.

Marzałek, Magdalena, and Sylvia Sasse, eds. 2010. Geopoetiken: Geographische Entwürfe in Den Mittel- und Osteuropäischen Literaturen [Geopoetics: Geographical Concepts in Central and Eastern European Literatures]. Berlin: Kulturverl. Kadmos.

Mazierska, Ewa. 2010. "Eastern European Cinema: Old and New Approaches." Studies in Eastern European Cinema 1 (1): 5-16.

Petrić, Vlada. 1978. “Dziga Vertov as Theorist.” Cinema Journal 18 (1): 29-44.

Pfaller, Robert. 2007. "Die Rationalität der Magie und die Entzauberung der Welt in der Ideologie der Gegenwart." [The Rationality of Magic and the Demystification of the World in Contemporary Ideology.] Kultur \& Gespenster 3: 14-35.

Pieldner, Judit. 2016. "Magic Realism, Minimalist Realism and the Figuration of the Tableau in Contemporary Hungarian and Romanian Cinema." Acta Universitatis Sapientiae, Film and Media Studies 12: 87-114.

Pop, Doru. 2014. Romanian New Wave Cinema: An Introduction. Jefferson, NC: McFarland \& Company.

Popović, Gordana. 2015. “Ideologija i masovni ornament." [Ideology and Mass Ornament]. Politika. Kulturni dodatak, March 15.

Șerban, Alina. 2010. "Note on the 'Seductiveness of the Interval'." In The Seductiveness of the Interval. Romanian Pavilion: 53rd International Art Exhibition, edited by Ştefan Constantinescu, Andrea Faciu, and Ciprian Mureşan, 7-8. Stockholm: Romanian Cultural Institute of Stockholm. 
Simons, Daniel J., and Christopher F. Chabris. 1999. "Gorillas in our Midst: Sustained Inattentional Blindness for Dynamic Events." Perception 28: 1059-1074.

Virginás, Andrea, ed. 2016. Cultural Studies Approaches in the Study of Eastern European Cinema: Spaces, Bodies, Memories. Newcastle upon Tyne: Cambridge Scholars Publishing.

Virilio, Paul. 1993. “The Third Interval: A Critical Transition.” In Rethinking Technologies, edited by Verena Andermatt Conley and translated by Tom Conley, 3-12. Minneapolis: University of Minnesota Press.

Vujanović, Ana. 2013. “Crni Talas’ Jugoslovenskog Sleta: Dan Mladosti 1987.i 1988.” TkH časopis za teoriju izvođačkih umetnosti 21: 21-27.

White, Kenneth. 1987. "Élements de géopoétique." [Geopoetic Elements.] In L'Esprit Nomade, edited by Kenneth White, 272-293. Paris: B. Grasset. 